\title{
River-Based Cultural Landscapes and the Challenges of Flood Disaster in the Tropics
}

\begin{abstract}
Adhuze, Olasunmbo* and Ayeni, Dorcas**
*Department of Architectural Technology, The Federal Polytechnic, Ado Ekiti, Ekiti State.

${ }^{* *}$ Department of Architecture, The Federal University of Technology, Akure, Ondo State.

Abstract

Cultural Landscapes are unique in their appeal not only to the host communities but more to tourists and serve more than the purpose of mere sightseeing, they are enriched with physical tangible and intangible qualities of our heritage. The history of a people are often woven around such environments because their socio-religious links are without a doubt attached to it. These sites, apart from its historical qualities contain natural elements such as rocks, hills, rivers, caves and are today developed for tourism with so much investment being committed to achieving maximum benefits of tourism. However, with the challenges of climate change and most especially flood for sites which are river-based, hopes may be dashed, and development swept away just in one episode of flood when prevention is not considered. This paper, therefore, examines the challenges of flood on such heritage sites using the Osun-Osogbo Grove as a case study. Observation method was used to gather necessary information from tour guides and frequent users of the site. It holds that in the redesign of such sites, integration of control, mitigation of flood risk and other man-made enclosures is essential to cope with the challenge and therefore prevent destruction. It then discusses some of the ways these design goals can be accomplished. It closes by recommending how the strategies can be propagated to the stakeholders.
\end{abstract}

Keywords- Cultural landscape, Disaster, Flood, Osun Osogbo Grove, Risk Control

DOI: $10.7176 / \mathrm{JEES} / 9-7-06$

Publication date:July $31^{\text {st }} 2019$

\subsection{Introduction}

The cultural landscape, a geographical area which is a combined work of nature and man, also subjected to time but is gradually becoming a place where people want to be identified with because of the recent global attention that is being paid to it. Because of its identity, these places are primarily developed for tourism in many areas where they are located and are fast becoming a major tourist attractions world over. Tourism in recent times has become a significant income earner, statistics say tourism is the second largest industry that has contributed to the socio-economic growth of many countries (Ejaetal, 2012; Ojo, 2014). Tourism industry indeed promotes cultural exchange among countries of the world through the interactions that take place between tourists of foreign descent with the locals of the tourist site. Tourism is about meeting other people, and this gives a picture about the tourist, his/her personality, attitude, values and lifestyle all of which are shared with the locals of the tourist sites through the necessary interaction.

Although, the tourism industry is a vehicle for promoting cultural exchange that enhances international understanding and goodwill among the diverse peoples of the world, it is also a catalyst for enhancing many country destination employment opportunities, foreign exchange and infrastructural facilities, where a wellplanned developmental strategy is put in place. (ESCAP, 2002; cited in Ejaetal, 2012). The geographical location upon which the activity of tourism is going to be carried out is just as important as the activity itself. It therefore makes a logical sense to say that before the socio-economic and physical benefits of tourism can be harnessed, utmost relevance should be accrued to that site in its conservation and protection in the face of the challenging environmental problems of climate change and especially the river-based tourist site.

Challenges of climate change are enormous and despite all the attention being paid to it, the challenges are not abating. This is not because all concerned are not doing the right thing, (although not all nations have keyed into the plan of doing the right thing) but more importantly because the earth is still going through the disaster that had previously and is continuously being created by man. Climate change is an offshoot of environmental degradation which is basically caused by man. Environmental degradation has been caused by human activities such as the burning of fossil fuel for heat and energy, deforestation, the release of harmful chemicals into the atmosphere from industries (NRC, 2010). In depreciating the environment, harm is not only brought upon the living spaces of man, danger is simultaneously brought to the heritage and tourist sites and especially those that are water based due to the disaster such as flood that will be caused by the degradation. The after effect is the unwarranted and unexpected volume of destruction that will be unleashed on these sites and the economic and social destruction it will bring to all the stakeholders. 
It therefore portends that if the socio-economic benefits of tourism are going to be harnessed on a tourist site, the nature of the development that should be attended to that site should be to protect and preserve its environment from the dangers of climate change and especially flood in this case where water is the main attribute of the site. Several authors have carried out research on flood change and its effects on the human environment but very few are looking at the challenges of the environment on tourism sustainability. It is therefore, the position of this work to examine the possibilities of flood on the United Nations Economic Social and Cultural Organization's World Heritage Site, Osun Osogbo Grove and to propose ways of ameliorating the effects of flood on the site.

\subsection{Cultural Landscape}

Wherever man is, there is movement in and around, and in every community, people move in and out of places every day; generations of humans have done so throughout history (Alabi, Adebisi and Ajadi 2010). The patterns of movement of the people reflect the conditions of an ever-changing world and this resultantly impacts the culture on the landscapes of the places they leave and the places they settle in ways that often last well beyond their lifetimes. These imprints on a region include its cultural make-up, spoken languages, sacred institutions, ethnic diversities, architectural styles, and other cultural markers; all clues to the past, present, and future of that area and generations of the people (Nora, Mechtild and Pierre-Marie, 2009; Haenraets 2010). Culture cannot be taken away from the people neither the people from the culture. To this effect, wherever man gets to, he leaves his prints in the sands of time and depending on the importance attached to these prints, a "mark" is made. Where such "marks" are of great importance, such places are termed "sacred" as the history and importance of such places are handed down from one generation to the other. Such places are today termed cultural or heritage sites, iconic places which dot landscapes all around the world and are found in almost all tribes and places with human affiliation. To all people are varied things, events and places of importance and these exist in all culture, but it could not be said that every place of importance to peoples is cultural landscape. This is so because a cultural landscape is not just determined by sentiments or emotions but by its impact on the environment and the generality of the people.

These places which exist in different geographical regions stand to be pull agents for people to visit for various reasons which according to Gumel (1988) and Bell-Gam (2009) include among other things, merrymaking, festivals, cultural visitation, and exchange, traveling for commerce and health purposes which are basic features of tourism. But where tourism operates, there are various positive and the negative demands. In the opinion of Lea (1993) tourism results in a complex series of economic, environmental, and social impacts on societies which include the economic contributions of foreign exchange earnings and the balance of payments, the generation of employment and of income, the improvement of economic structure and the encouragement of entrepreneurial activity. The social and the environmental impacts are not lacking but also the negative series which include, environmental degradation, pollution, increased waste generation, infiltration of foreign culture, depletion of available resources and especially cases of flood which can wipe out the whole investment of years in just one occurrence. The predictions of global warming by researchers indicate that the sea level will continue to increase due to the melting of the ice caps and glaciers, storms expected to be more frequent and devastating as we have observed in the United States with the hurricanes. As the sea invades the mouth of the rivers, flooding from runoff will increase upstream. (Hart, 2006). Ocampo (2013) and Dongman et al. (2014) stated that 33 countries of the world had been predicted to be at extreme risk of flooding, where sixty-one percent of these will be in sub-saharan Africa and Nigeria being in the sixth position of the countries that would be worst hit. Studies have warned that if no mitigation steps are taken, flood will cost annual damages of one trillion dollars by the year 2050. It therefore becomes imperative that at a cultural landscape, which is an income generator for all the stakeholders and a heritage site for a race, adequate protection has to be provided to prevent destruction from natural disasters such as flood.

\subsection{Flood disasters and its effects on tourism: an overview}

Human activities over the decades have contributed immensely to the challenges that the earth is going through at the moment. This stems out of a constant activity of the humans which consciously or unconsciously causes emission of greenhouse gases which depletes the ozone layer and causes the atmospheric temperature to increase. These human activities include and not limited to; burning of fossil fuels for heat and energy, deforestation, use of chemicals for both industrial and agricultural purposes, storing of wastes in landfills, gas flaring, etc.

At a workshop on flood coordination held in 2013, it was reported that in the 2012 floods in Nigeria displaced 2.3 million people from their homes and another 363 people lost their lives. It was further reported that 16 million people in 108 local governments negatively affected, this could be as loss of farm animals, produce or even cultivated farmland. Total losses from the flood of 2.6 trillion Naira or \$16.9 billion (Flood report, 2013). The cases of flood disaster did not just occur in 2012, In 2010, about 1,555 people were killed and 258,000 more displaced as properties worth billions of naira were destroyed. Unfortunately, flooding is a recurring phenomenon in most cities of Nigeria and stakeholders have not yet come to the reality of this effect of climate change in order 
to take a decisive step at ameliorating its effects. On the 26th of August 2011, the flooding disaster which occurred in Ibadan metropolis caused monumental destructions in the city (Efobi and Anierobi, 2013) and in June 2018 in Abeokuta in Ogun state of Nigeria, properties worth millions of Naira were lost to flood within the metropolis.

Flood impact on tourism sites can be assessed through economic impacts, socio-cultural impacts, environmental impacts and other related impacts on society (Klijn et al., 2015; Arvind et al., 2016). But according to Few, 2003; Kyriakidis and Partner, 2008; and Zahed et al., 2014, despite the growing threat of floods to tourism businesses and destinations, only a few tourism businesses are prepared enough to handle the impacts. The flooding impacts on tourism sectors have become widespread and expose the lack of mitigation plans and are generally assessed and evaluated economically to understand the purpose and nature of the business (Changnon, 1998; Brody et al., 2007; Atta-ur-Rahman and Khan, 2011; Kundzewicz et al., 2013). The socio-cultural and the environmental effects are also wide and varied, affecting both the natural and man-made elements of tourism and other tourism activities. Flooding has affected the geographical setting, landscape, activities and attractions of the tourism accommodation sector (Berrittella et al., 2006; McEvoy et al., 2008; Yu et al., 2009; Wyss et al., 2014).

Tourism has long been recognized as an impetus in bringing business opportunities, ranging from a small scale to a largescale business venture as well as from nature-based attractions to cultural based tourism attraction (Denicolai et al. 2010, Hamilton et al. 2005, Ritchie 2004, Ayeni 2012a). As an industry, many factors determine the influx of tourist arrivals, not only confined to offerings of attractive man made products, nature of the environment, hospitality or receptiveness of the local community, provision of the basic amenities but also with the natural environment, including good weather and unique climate features (Berrittella et al. 2006, EugenioMartin \& Campos-Soria 2010). Nevertheless, tourism is vulnerable to climate, natural disasters and hazards (Ritchie 2004, Scott \& Lemieux 2010, Hall 2010) and its vulnerability is more prominent and disastrous at sites which their major attractions are based on water which are more prone to the challenges of floods and upon which the developments of tourism can be wiped out in one disastrous episode of flood. The import of this can result into the loss of patronage from tourists who planned visiting the site and also a loss of investment in the site and in the daily activities to give tourists the best experiences. This will definitely reduce the number of visitors that visit the site and affect the economic and social character of the site, disrupt tourism activities and quash businesses for entrepreneurs.

The disruption of nature and heritage in a developed cultural landscape site is another challenge which flood can cause. It will cause a loss of asset which will eventually weaken the strength to attract eco-tourists. A disruption of the eco-system can also be an effect of flood (Hamzah et al, 2012). Definite plants and animals can be lost or temporarily vacate the site due to the flood, thus affecting the traffic flows of eco-tourist. Bio-diversity which is a major point of attraction to natural sites are easily lost which means a loss of tourism potential of such site (GhulamRabbany et al., 2013).

Much less from the natural substances that are lost to flood are the loss of social amenities which had been invested upon both in monetary terms and in manpower delivery. Although it could be said that these items can be recovered or reproduced unlike the natural items when lost to the flood, it is much better to be prevented from destruction of the flood. When flood occurs, it contaminates all water sources which disturbs the sanitation of the environment and can then aid in the quick spread of diseases.

\subsection{METHODOLOGY \\ 4.1 STUDY AREA}

The dense forest of the Osun Sacred Grove whose landscape and its meandering river is dotted with sanctuaries and shrines, sculptures and art works in honour of Osun (the river goddess) and other deities are located in the heart of the capital city Osogbo of Osun State as shown in plate 1. It stands as one of the last remnants of primary high forest in southern Nigeria with protected relics of older generation that habour the goddess of water who comes out once every year to bless and heal the infirmities of the land (Oni, 2016). The grove sits on a 75 hectare of land and is regarded as the abode of the goddess of fertility Osun, one of the pantheons of Yoruba gods (UNESCO, 2013). The sacred grove, which is now seen as a symbol of identity for all Yoruba people, is probably the last in Yoruba culture. Within the forest sanctuary are forty shrines, sculptures and art works erected in honour of Osun and other Yoruba deities, many created in the past forty years, two palaces, five sacred places and nine worship points strung along the river banks with designated priests and priestesses. There is an annual festival held in honour of the Osun deity in the grove which draws both the adherents of Osun and a heavy presence of local and foreign tourists. It is one of the most recognized African festivals that attracts over one million tourists across the globe and one of the major cultural assets that attracts world attention in Nigeria (Olukole, 2014). With all 
these exposures already accrued to the grove, it stands as an appropriate location to look at the challenges of flood on tourism.

Plate 1: Google site of Osun Osogbo Grove.

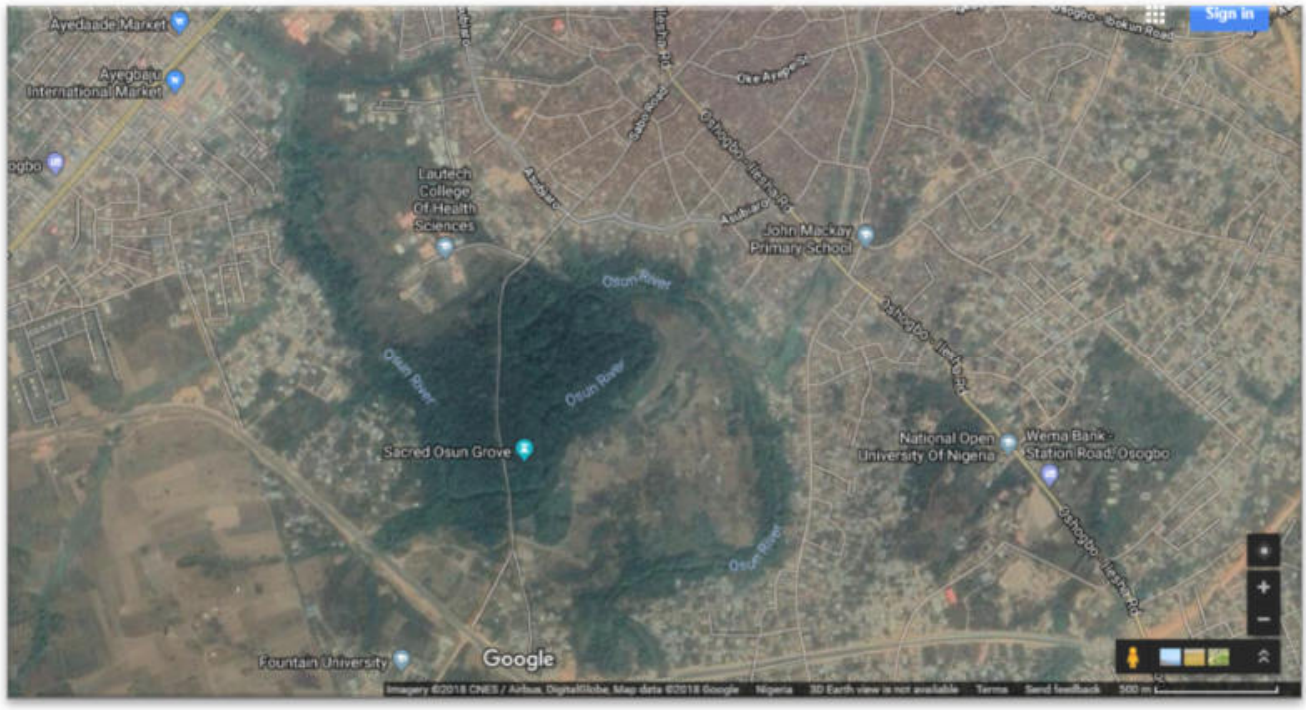

Plate 2: The Osun Osogbo River

Source: Google maps, 2017

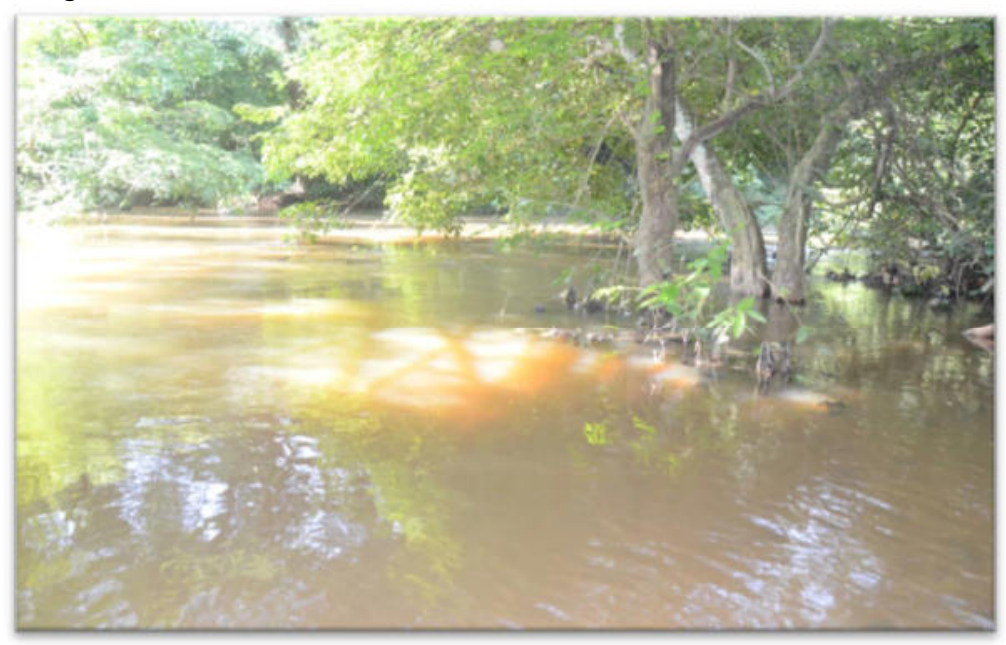

Source: Authors' field work, 2018

\subsection{RESEARCH STRATEGY AND ANALYSIS}

This work adopts the qualitative data of observation method as the primary source of data collection. Observational method involves making observations of behavior within an environment and methodically recording those observations in an objective manner in order to describe the behaviour (Stangnor, 2011). Observation the systematic description of events, behaviors and artefacts in the social setting chosen for study (Kawulich, 2005). The study used a direct observation of watching rather than taking part and be unobtrusive as possible so as not to bias the observation. This method was used in order to afford the researchers the opportunity to carry out an onsite research as to the effect and extent of flood on the site. This study observed the attitude people take towards the wet cultural landscape, both tourists and adherents of the deity in order to get firsthand knowledge of how people behave within the grove.

The Osun Osogbo grove is, a cultural landscape that has its essence on the river Osun which flows through the site. The river is regarded as one which the goddess of fertility resides and this serves as a pull factors for some 
tourists and worshippers of the goddess. Rivers and water bodies according to Akingbohungbe (2006) is a natural element of the environment to which people respond spontaneously, watching reflections and can be used to advance peoples' environment intercourse, thereby enriching the sense of place and memories of such location. This can only be achieved when there is no perceived threat to the lives of the locals and tourists alike. The river bank at the Osun Osogbo grove is left bare and unprotected and no security measure is put in place to protect observers in case of incidences. There is also no provision of emergency aids for visitors either as physical human guards and rescuers or structural elements, to guide as support which visitors and worshippers can hold unto in case of crises. At such times when the tide is high, the river bank is considered scary by observers and tourists and unapproachable, this makes the river bank unfriendly to tourists, and so, tourism experiences may be reduced to that effect and tourism activity unachievable and defeated.

Moreso, there are artifacts and historic places in and at this river bank which are prone to being affected by flood when there is a case of such. The stool (rock) which the Ataoja seats annually to commune with the river goddess during the festival is located a few meters into the river and this can easily be covered by flood and diminish tourist's experiences. Likewise, the old Palace of the "Ataoja" (the King of Osogbo empire) and a pavilion a situated in a close proximity to the river with a few other shrines. Although the pavilion is recently built to provide a sitting space for visitors who come around during the festivals and located as such for direct view to the river, the old palace is one of the major attributes of the site which had been in existence for decades and require protection from flood and any other environmental hazard. All these when lost to flood can destroy the symbols of cultural heritage and the tourism potentials of the site.

\section{Plate 3: Osun Osogbo River Bank}

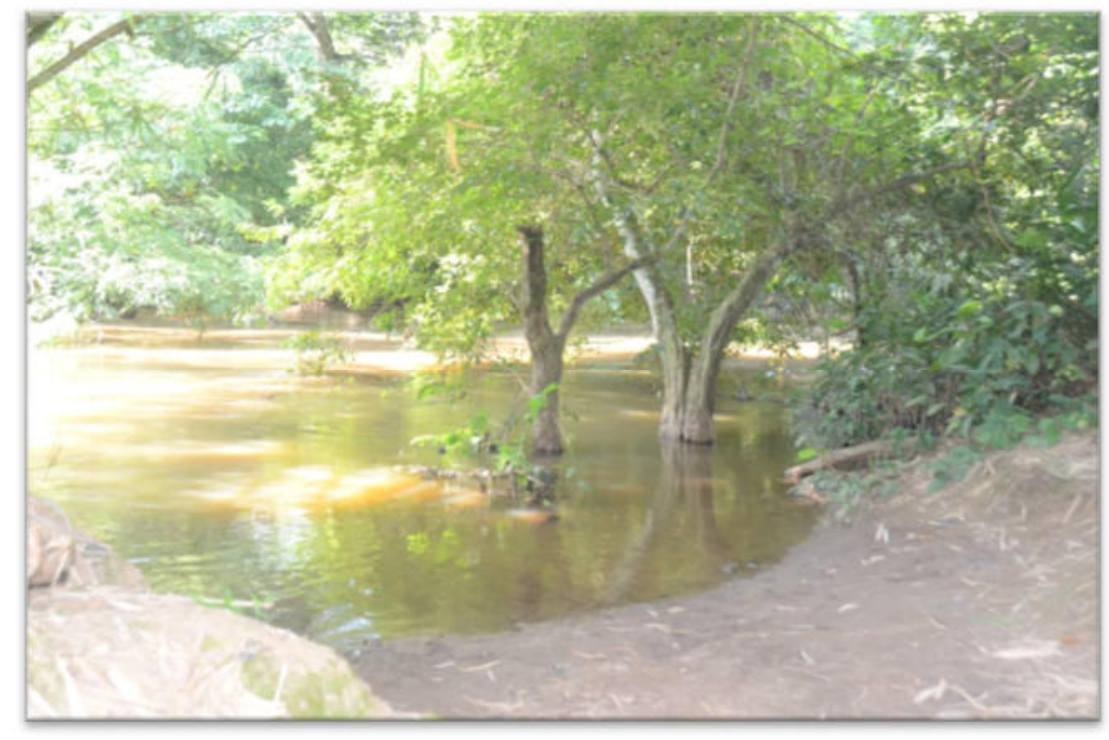

Source: Authors' field work, 2018

Every year, the Osun Osogbo grove play host to thousands of local and international tourists at the Osun Oshogbo annual festival which holds during the month of August at the Grove, with Osun worshippers from all over the world worshipping the Osun Deity in a two week long programme. This festival holds to reestablish the mystic bonds between the Osun goddess and the people of the town. The festival is a religious event to soothe and adore Osun--the Yoruba female deity goddess of beauty and fertility. This goddess is believed to have the power to heal, grant wealth and protect the people of the land and especially her faithful believers (Omojola 2010). Because of its spiritual inclination, the grove is always open to people who wish to take out of the river for cleansing, drinking, bathing and the likes. Visitors therefore, make their ways to the river on a daily basis to fetch from the river, in such cases, plastic containers easily flow away from such people into the river posing environmental danger to the aquatic lives. Although, this may not necessarily be due to flood, but it poses a challenge to the sustainability of the immediate and larger environment.

Flood is an environmental hazard, it destroys everything in its path including the plants and animals. The grove is a protected forest and actually the last remnants of the Yoruba forests, therefore, this forests have rare plants species which cannot be allowed to be lost to flood cases. These plants are often used as herbs for healing, 
protection and even as food to the local community and as such requires adequate preservation. It is an above for biodiversity and ecological preservation, it hosts rare species of monkey, snakes, birds and other animals, it likewise is the abode of different species of plants. In 2005, it was nominated as a UNESCO world heritage site and has placed Nigeria among other countries on the UNESCO seat. Before this time, it has been open up for tourism, where thousands of tourists visit the site during the annual festival. With all these attributes of the site, great effort at preservation of these heritage site is required to promote its sustainability. It has been a major source of foreign exchange for the country and a basis for income revenue for the state government and the local community. The site plays host to flora and the fauna which are local to the site and which requires the preservation of the site and ultimately, the culture of the people which it has held strong for centuries and tucked deep in the fabric of this heritage site.

\subsection{Strategies for Controlling and Palliatives Measures of Flood Risk at Osun Osogbo Grove}

With the challenges and the observations already made as to the risks of flood at the grove, it is important to create preventive elements and safety measures for both lives and properties to safeguard tourism investments and uphold tourists' interest on the site. Therefore, the following strategies have been proposed as palliative measures to reduce destruction in case of flood.

\subsection{Proper landscape design}

There is the need to focus on improving on the physical look of many of the Osun Osogbo Grove through adequate provision of landscape elements. Landscape plays the job of the improvement of tourism advancement and the entire environment whereupon it is sited; the purpose behind this affirmation is that landscape alludes to the mix of natural, social, physical and symbolic components, and highlights features on land that are the results of the interactions between human and the natural environments (Supplementary Planning Guidance, 2004; Ayeni, $2012 \mathrm{~b}$ ). Given this perplexing relationship that exists between landscape, tourism, and the natural environment, it is significantly critical to adopt and more sustainable approach to deal with the advancement of the forest to make it all the more engaging and more secure for tourists to patronize, particularly the planning and management of landscapes which will also ameliorate the incidences of flood on the site. The planting of more species of trees, shrubs and the introduction of soft paving will go a long way to control surface water. The location of new structures should be planned by professionals so as not alter the flood path. This will also ensure a landscape that supports the ecological processes and guarantee biodiversity in order to protect the loss of tourism potentials (Sunlu, 2003; Opdam, Steingrover, and Rooij, 2006). Undeniably, the Scottish Natural Heritage (2003), considered the quality of the environment important for functional, aesthetics, scientific and economic reasons; ensuring that the environment remain useful by providing safety, tranquility, and recreational opportunities for tourists and the locals which is what should also be sought after in a location such as the Osun grove

\subsection{Barriers}

The introduction of passive flood barriers at the waterfront will help save lives and properties. Such barriers will serve as temporary measures to curtail the flow of the flood to save some time for evacuation of the people around the river. Barriers can also be mounted to define the limit where tourists can reach in the river to prevent occurrences of being swept away by the tides and probable death in the river. These barriers while they serve as structural and aesthetic elements can also serve as prosthetics along the walk paths for support to the weak visitors.

\subsection{Observatory platforms}

Building observatory platforms, at different areas of the site where visitors can stand and observe activities going on at the river bank is of great importance. This will prevent crowding at the river bank and possible dangers. These observatory platforms will be elevated from the ground to a level which people standing on it can have a clear and unobstructed view from any direction. This kind of platform can also be used by researchers and security for different types of monitoring. The structure will go in line with the demands of the international organization in charge of the site (ICOMOS) which requires that structures coming on the site will be built of local materials such as clay and stone.

\subsection{Structural defenses}

River flooding can be controlled along its pathway with basic protections which are permanent structures, for example, waterway dividers, dikes and boundaries. These will keep the surge from getting to the receptors at whatever point the waterway floods its bank. This measure gives protection against the dangers of flood. 
Plate 4: Osun Osogbo River Bank

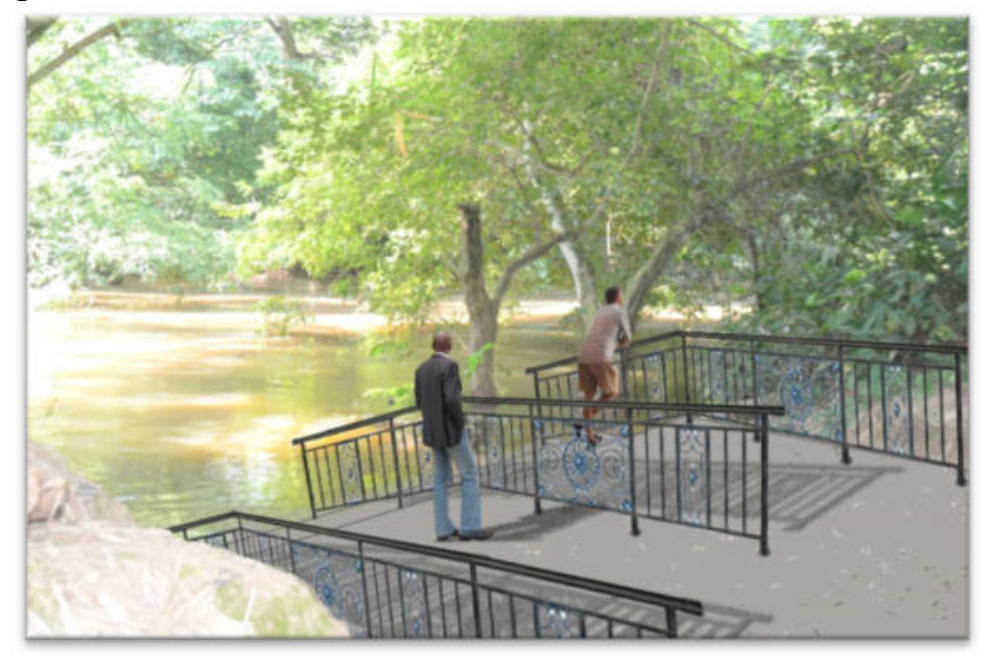

Proposed paradigm for the structural defense and steps into the river Source: Authors' proposal

\subsection{Improved environmental management and planning}

Sound environmental management of tourism facilities can expand the advantages to natural environment. Be that as it may, this requires cautious planning for controlled development, in light of investigation of the environmental resources of the area. Planning helps to make choices on decisions between inharmonious uses, or to discover approaches to make them attuned to the plan. By proper and timely planning for tourism improvement, harmful and costly errors can be averted, avoiding the gradual deterioration of environmental assets significant to tourism. Cleaner creation systems can be important tools for planning and operating tourism facilities in a way that limits their environmental impacts. For instance, using energy-efficient and non-polluting construction materials, sewage systems and energy sources is an increasingly important way for the tourism industry to decrease its impact on the environment.

\subsection{CONCLUSION AND RECOMMENDATION}

In this work, it has been discovered that the effects of climate change will in no small measure affect tourism, especially in water-based tourist sites which are prone to flood. The challenges of flood will adversely affect tourism if the necessary preventive measures are not put in place. This work has emphasized that control and mitigation of flood risk need to be integrated at a waterbased tourist site to enhance tourist experiences and also preserve and protect tourism development at the World Heritage Site. The work has consequently proposed measures to prevent the occurrence of flood and ameliorate its effect at the site, such measures include, introduction of structural defenses, proper landscaping of the site, improved environmental management and planning etc.

In considering the sustainable Development Goals, climate action, the thirteenth goal and good health and wellbeing, the fourth article which can be a fallout of good tourism experience are major issues which have been analyzed in this work. With the trend of the development of tourism world over, it is high time a greater attention is paid to the Nigerian tourism sites to promote economic and social standards for the people of the locality and the country at large. Since the Osun Osogbo grove is one of the last remnants of the sacred groves in Yoruba land, it therefore, becomes imperative that serious effort is made by all stakeholders at preserving every bit of the grove for the sake of posterity.

\section{References}

Akingbohungbe, D.O. (2006). Site planning and design for contemporary housing environment in Nigeria. The Architect's Perspective. In Urban Environment Sustainability: interventions and responses, Fadamiro, J.A., Atolagbe, A.M.O., and Olujimi, J.A.B. eds., Akure Urban Design Research Team, 151-158.

Alabi, F.M, Adebisi, J.A and Ajadi, K.O. (2010). Tourism development: Strategy for positioning Nigeria in the world's tourism ranking, Environ-link, Journal of Environmental Issues, 3(1), 114 130 
Arvind, C.S., Vanjare, A., Omkar, S.N., Senthilnath, J., Mani, V. \& Diwakar, P.G. (2016). Flood Assessment using Multi-temporal Modis Satellite Images. Procedia Computer Science, $89,575-586$.

Atta-ur-Rahman \& Khan, A.N. (2011). Analysis of flood causes and associated socioeconomic damages in the Hindukush region. Natural Hazards, 59(3), 1239-1260.

Ayeni, D.A. (2012a). Enhancing and Developing Sustainable Tourism Through Landscaping In Nigeria. (Doctoral dissertation, De Montfort University, Leicester, United Kingdom). Retrieved from https://wscholars.com/index.php/ajtr/article/download/194/114.

Ayeni, D.A (2012b). Enhancing the Nigerian Tourist Attractions through Landscaping for Sustainable Tourism Development. American Journal of Tourism Research. 1 (2), 59-66

Bell-Gam, L. (2009). Strategies for the development of tourism and theatre industries in Nigeria: Rivers State Perspective. Creative Artist: A Journal of Theatre and Media Studies. 3(1) 1-9

Berrittella, M., A. Bigano, R. Roson, \& S.J. Richard T. (2006). A general equilibrium analysis of climate change impacts on tourism. Tourism Management, 27: 913-924.

Brody, S.D., Zahran, S., Maghelal, P., Grover, H. \& Highfield, W.E. (2007). The Rising Costs of Floods: Examining the Impact of Planning and Development Decisions on Property Damage in Florida. Journal of the American Planning Association, 73(3), 330-345.

Changnon, S.A. (1998). The Historical Struggle with Floods on the Mississippi River Basin -Impacts of Recent Floods and Lessons for Future Flood Management and Policy. Water International, 23(4), 263.

Denicolai, S., G. Cioccarelli, \& Zucchella, A. (2010). Resource-based local development and networked core competencies for tourism excellence. Tourism Management., 31: 260-266.

Dongman, B., Hochrainer-Stigler, L., Feyen, C.J.H., Aert, R., Mechler, W.J.W., Botzen, L.M., Bouwer, G.P., Rojas, P., and Ward, P.J (2014). Increasing stress on disaster-risk finance due to large floods. Nature Climate Change, 4(4); 264-268

Efobi, K and Anierobi, C (2013) Urban Flooding and Vulnerability of Nigerian Cities: A Case Study of Awka and Onitsha in Anambra State, Nigeria. Journal of Law, Policy and Globalization.

Eugenio-Martin, J.L. \& Campos-Soria, J.A. (2010). Climate in the region of origin and destination choice in outbound tourism demand. Tourism Management, 3(6):744-751.

Few, R. (2003). Flooding, vulnerability and coping strategies: local responses to a global threat. Progress in Development Studies, 3(1), 43-58.

Flood report (2012). Building a Coordinated Approach to Flood Disasters in Nigeria. Centre for Human Security of the Olusegun Obasanjo Presidential Library Foundation.

Hall, C.M. (2010). Crisis Events in Tourism: Subjects of crisis in tourism. Current Issues in Tourism, 13(5): 401-417.

Hart, J. (2006). The Environment. Microsoft Encarta. Redmond, W.A: Microsoft Incorporated, Inc.

Haenraets, J (2009). Identifying key problems regarding the conservation of designed landscapes: landscapes of the recent past. (Doctoral dissertation). De Montfort University, Leicester, United Kingdom.

Hamilton, J.M., J. David Maddison, S.J. Richard T. (2005). Climate change and international tourism: A simulation study. Global Environmental Change, 15: 253-266.

Hamzah, J., Habibah, A., Buang, A., Jusoff, K.,Toriman, M.E., Mohd Fuad, M.J., Er, A.C. and Azima, A.M. (2012). Flood Disaster. Impacts and the Tourism Providers' Responses: The Kota Tinggi Experience. Advances in Natural and Applied Sciences, 6(1), 26-32.

Kawulich, B.B. (2005). Participant Observation as a data collection method. Qualitative Social Research, 3(10), 240-252.

Klijn, F., Kreibich, H., de Moel, H. \& Penning-Rowsell, H. (2015). Adaptive flood risk management planning based on a comprehensive flood risk conceptualisation. Mitigation and Adaptation Strategies for Global Change, 20(6), 845-864.

Kundzewicz, Z.W., Kanae, S., Seneviratne, S.I., Handmer, J., Nicholls, N., Peduzzi, P., Mechler, R., Bouwer, L.M., Arnell, N., Mach, K., Muir-Wood, R., Brakenridge, G.R., Kron, W., Benito, G., Honda, Y., Takahashi, K. \& Sherstyukov, B. (2013). Flood risk and climate change: global and regional perspectives. Hydrological Sciences Journal, 59(1), 1-28.

Kyriakidis, A. \& Partner, G.M. (2008). Too Hot to Handle? The Hospitality Industry Faces. Tourism, 71-81.

Lea, J. (1993). Tourism and Development in the Third World. New York: Routledge.

McEvoy, D., Cavan, G., Handley, J., McMorrow, J. \& Lindley, S. (2008). Changes to Climate 
and Visitor Behaviour: Implications for Vulnerable Landscapes in the North West Region of England. Journal of Sustainable Tourism, 16(1), 101-121.

Nora P, Mechtild M, and Pierre-Marie, R. (2009). World Heritage Cultural Landscapes, Handbook for Conservation and Management. Paris: UNESCO.

NRC, (2010). Advancing the science of climate change. National Research Council, Washington, D.C. U.S.A The National Academic Press.

Ocampo, A.R. (2013). Sub-saharan Africa, Southern Asia most at risk from climate change. Business Insight. Available from www.devex.com (accessed 17-05-2014)

Ojo, $\mathbf{J}$ (2014). Managing tourism for socio-economic development in Nigeria local government: A case of Idanre Local Government. Journal of African Studies and Development, 6(2) $29-35$

Olukole, T.O. (2014). Geographical information systems database of cultural heritage resources of Osogbo and their tourism potential. African Journal of Hospitality, Tourism and Leisure. 3 (2)

Omojola, B. (2010). Rhythms of the Gods: Music and Spirituality in Yoruba Culture. The Journal of Pan African Studies 3 (5): 23 - 58.

Opdam, P., Steingrover, E., \& Rooij, S. (2006). Ecological networks: A spatial concept for multi-actor planning of sustainable landscape. Landscape and Urban Planning, 75(3-4), 322332.

Ritchie, B. W. (2004). Chaos, crises and disasters: a strategic approach to crisis management in the tourism industry. Tourism Management. 25(6): 669-683.

Scott, D. \& Lemieux, C. (2010). Weather and climate information for tourism. Procedia Environmental Sciences, 1: 146-183.

Scottish Natural Heritage. (2003). Sustainable development and the natural heritage. Retrieved November 222016 from: http://www.snh.org.uk.

Stangnor, C. (2011). Research Methods for Behavioral Sciences (4 ${ }^{\text {th }}$ ed.). Belmont, USA: Wadsworth Cengage Learning.

Sunlu, U. (2003). Environmental impacts of tourism. In: Camarda D. (ed.), Grassini L. (ed.). Local resources and global trades: Environments and agriculture in the Mediterranean region. p. 263-270

Supplementary Planning Guidance. (2004). Landscape. Retrieved November 222016 from: http://www.npt.gov.uk/PDF/Landscape.pdf.

UNESCO. (2013). Osun Oshogbo Sacred Grove, World Heritage List. Retrieved from www.unesco.org//wto.

Wyss, R., Abegg, B. \& Luthe, T. (2014). Perceptions of climate change in a tourism governance context. Tourism Management Perspectives, 11, 69-76.

Yu, G., Zvi, S. \& Walsh, J.E. (2009). Effects of climate change on the seasonality of weather for tourism in Alaska. Arctic, 62(4), 443-457.

Zahed, G., Puad, M.S.A. \& C., H.J. (2014). When Disaster Strikes: The Thai Floods of 2011 and Tourism Industry Response and Resilience. Asia Pacific Journal of Tourism Research, 20(4), 399-415. 